\title{
Passivation process quality in reinforced concrete: effects of polarization periodicity and passivation consolidation parameters on data processing
}

\author{
J. A. Briceño-Mena ${ }^{1(D)}$, M. G. Balancán-Zapata ${ }^{1(D)}$, P. Castro-Borges ${ }^{1 *}$ (iD) \\ *Contact author: pcastro@ cinvestav.mx \\ DOI: $\underline{\text { http://dx.doi.org/10.21041/ra.v10i2.466 }}$
}

Reception: 13/12/2019 | Acceptance: 24/04/2020 | Publication: 30/04/2020

\begin{abstract}
The passivation process quality was studied considering polarization periodicity, passivation consolidation parameters, and data processing. Passivation process quality in steel reinforcement affects a structure's planned future service life. Some research has addressed this phenomenon, but its study is complicated by the limits of analog-era data, dispersion in corrosion rate data, and their interpretation. Two series of small reinforced concrete specimens were built using two water/cement ratios and two curing/storage combinations and exposed to the marine environment. Polarization periodicity did not affect passivation/depassivation during passivation but on the data processing. The curing and storage process influenced the tendency towards depassivation. Post-curing storage type affected the cumulative corrosion rate from 1 to $5 \mu \mathrm{A} *$ day $/ \mathrm{cm}^{2}$; this is equivalent to the margin of uncertainty in interpretation.

Keywords: cumulative corrosion rate, w/c ratio, reinforced concrete, tropical marine environment.

Cite as: Briceño-Mena, J. A., Balancán-Zapata, M. G., Castro-Borges, P. (2020), "Passivation process quality in reinforced concrete: effects of polarization periodicity and passivation consolidation parameters on data processing", Revista ALCONPAT, 10 (2), pp. 243 - 258, DOI: http://dx.doi.org/10.21041/ra.v10i2.466.
\end{abstract}

${ }^{1}$ Centro de Investigación y de Estudios Avanzados del IPN, Unidad Mérida, km. 6 Ant. Carr. a Progreso, 97310 Mérida, Yucatán, México

\section{Legal Information}

Revista ALCONPAT is a quarterly publication by the Asociación Latinoamericana de Control de Calidad, Patología y Recuperación de la Construcción, Internacional, A.C., Km. 6 antigua carretera a Progreso, Mérida, Yucatán, 97310, Tel.5219997385893, alconpat.int@gmail.com, Website: www.alconpat.org

Responsible editor: Pedro Castro Borges, Ph.D. Reservation of rights for exclusive use No.04-2013-011717330300-203, and ISSN 2007-6835, both granted by the Instituto Nacional de Derecho de Autor. Responsible for the last update of this issue, Informatics Unit ALCONPAT, Elizabeth Sabido Maldonado, Km. 6, antigua carretera a Progreso, Mérida, Yucatán, C.P. 97310.

The views of the authors do not necessarily reflect the position of the editor.

The total or partial reproduction of the contents and images of the publication is strictly prohibited without the previous authorization of ALCONPAT Internacional A.C.

Any dispute, including the replies of the authors, will be published in the first issue of 2021 provided that the information is received before the closing of the third issue of 2020. 


\title{
Calidad del proceso de pasivación en concreto reforzado: efectos de la periodicidad de la polarización y los parámetros de la consolidación de la pasivación en el procesamiento de datos
}

\begin{abstract}
RESUMEN
La calidad del proceso de pasivación se estudió considerando la periodicidad de polarización, los parámetros de consolidación de pasivación y el tratamiento de datos. Algunas investigaciones han abordado la calidad del proceso de pasivación, pero su estudio se complica por la limitación de los datos de la era analógica, la dispersión de éstos y la interpretación de la velocidad de corrosión. Se construyeron dos series de especímenes de concreto reforzado utilizando dos relaciones agua/cemento y dos combinaciones de curado/almacenamiento y se expusieron en un medio marino. La periodicidad de la polarización no tuvo efecto sobre la pasivación/despasivación durante la pasivación, sino sobre el tratamiento de los datos. El proceso de curado y almacenamiento influyó en la tendencia a la despasivación. El tipo de almacenamiento posterior al curado afectó la velocidad de corrosión acumulada de 1 a $5 \mu \mathrm{A}^{*}$ día $/ \mathrm{cm}^{2}$; esto es equivalente al margen de incertidumbre en la interpretación.
\end{abstract}

Palabras clave: velocidad de corrosión acumulada; relación a/c; concreto reforzado; ambiente tropical marino.

\section{Qualidade do processo de passivação em concreto armado: efeitos da periodicidade da polarização e parâmetros da consolidação da passivação no processamento de dados}

\begin{abstract}
RESUMO
A qualidade do processo de passivação foi estudada considerando a periodicidade da polarização, os parâmetros de consolidação da passivação e o tratamento dos dados. Algumas pesquisas abordaram a qualidade do processo de passivação, mas seu estudo é complicado pela limitação dos dados da idade analógica, pela dispersão destes e pela interpretação da taxa de corrosão. Duas séries de amostras de concreto armado foram construídas usando duas relações água / cimento e duas combinações de cura / armazenamento e expostas em um ambiente marinho. A periodicidade da polarização não teve efeito na passivação / despasivação durante a passivação, mas no tratamento dos dados. O processo de cura e armazenamento influenciou a tendência à despassivação. $O$ tipo de armazenamento pós-cura afetou a taxa de corrosão cumulativa de 1 a 5 $\mu \mathrm{A} * \mathrm{dia} / \mathrm{cm}^{2}$; isso é equivalente à margem de incerteza na interpretação.

Palavras-chave: taxa de corrosão acumulada; relação a / c; concreto armado; ambiente marinho tropical.
\end{abstract}

\section{INTRODUCTION}

In natural conditions, a layer of oxides that protects reinforcing steel is consolidated over time (Poursaee \& Hansson, 2007). This layer is formed due to the high alkalinity of the concrete and is known as the passivation layer (Andrade et al., 1995). This layer provides a barrier against aggressive agents, on whose stability of the passivation quality depends. Therefore, when the structures are exposed to an aggressive natural environment, the time for passivation to occur and consolidate is very important, since the electrochemical behavior of the reinforcing steel will 
depend on it and, therefore, its corrosion process (Ahmad \& Kumar, 2013), understanding as consolidation the electrochemical stability of the passive layer. There are studies on the passivation of the reinforcement, as well as the initiation and propagation stages of corrosion (Andrade et al., 1995; Huet et al., 2005; Jiang et al., 2017). However, the objectives of these studies did not necessarily took into account providing adequate times for steel to consolidate passivation (Poursaee \& Hansson, 2007). Furthermore, the variability in the study methods of passivation (Alonso et al., 2000; Jiang et al., 2017; Page, 2009; Poursaee \& Hansson, 2007) may cause a discrepancy in the interpretation of the same, causing it to have overestimation or underestimation values. Data on corrosion in reinforced concrete is commonly expressed as instantaneous corrosion

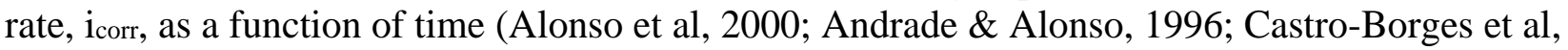
2013; Castro-Borges et al, 2017; Lopez \& Gonzalez, 1993; Pech-Canul \& Castro, 2002; Pedrosa \& Andrade, 2010; Rebolledo \& Andrade, 2010). Many studies include analysis of $i_{\text {corr }}$ behavior from the passivation zone to the moment when it begins to exhibit clear signs of depassivation. This helps in evaluating the corrosion resistance of different materials. Some works of both: before the 2000 year (Alonso et al., 2000; Andrade \& Gonzalez, 1978; Lopez \& Gonzalez, 1993) and after the 2000 year (Ghods et al, 2009; Pech-Canul \& Castro, 2002; Poursaee \& Hansson, 2007) sources, address the phenomena that occur before depassivation. However, the limitation of using analog data from earlier studies, and the intrinsic dispersion of $\mathrm{i}_{\text {corr }}$ data have delayed a deeper understanding of $\mathrm{i}_{\text {corr }}$ tendencies in the passivation zone. Previous studies (Andrade \& Alonso, 1996; Castro-Borges et al., 2013, 2017; Melchers \& Li, 2006; Pedrosa \& Andrade, 2010; Rebolledo $\&$ Andrade, 2010) include passivation zone analyses and some of them found interpretations of the data trends by applying straightforward mathematical processing, which of course would need to be confirmed under different exposure conditions.

The current practice of designing reinforced concrete structures with nearly one-hundred-year service lives implies the application of durability criteria to prevent corrosion. This calls for a much deeper understanding of corrosion in the passivation zone. Attaining passivation zone stability and durability require optimum concrete quality (curing conditions, water/cement ratio), knowledge of the exposure environment (prevailing and non-prevailing winds, the regime of temperature and relative humidity) and damage prevention measures (concrete cover, surface sealing) among other factors. An inadequate combination of these at an early age can negatively affect the passivation quality and future service life. The study of the passivation quality in the steel embedded in concrete is vital since it can significantly affect later electrochemical behavior and consequently a structure's short-, medium- and long-term service life.

However, routine procedures for long-term field studies, with a variety of combined objectives and different materials, do not easily allow a detailed study of the passivation quality at an early age, and therefore the impact of this situation is not known in the service life of the element. An example of this is usually when the measurements are performed in the field at intervals of low periodicity. This situation could mask trends that could be useful for service life models. For these reasons, doubts arose after more than ten years of experimentation (from 2007) in field specimens in which a relatively early depassivation process was expected, which did not occur. Then, it was decided to do, ten years later, another set of specimens (from 2017), in which some parameters in their composition and exposure would be modified to be able to analyze in more detail the quality of the passivation.

On the other hand, studying passivation quality requires full knowledge of the general criteria used to define a reinforcement bar as passive, in transition or active. The most accepted criterion is that passivation ends when the corrosion rate exceeds the $0.1-0.2 \mu \mathrm{A} / \mathrm{cm}^{2}$ range (Andrade \& Gonzalez, 1978; Berke et al, 1996), although some widely used criteria include a range of $0.1-0.5 \mu \mathrm{A} / \mathrm{cm}^{2}$ (Andrade \& Alonso, 1996; NMX-C-501-ONNCCE, 2015; Troconis et al, 1998). For practical purposes, a conservative criterion of values $<0.1 \mu \mathrm{A} / \mathrm{cm}^{2}$ indicates passivity in concrete 
reinforcement. Considering the above, the present study objective was to analyze the passivation quality in concrete reinforcement in terms of polarization periodicity during measurement, passivation parameters and data processing.

For this paper, only the data corresponding to a concrete cover of $20 \mathrm{~mm}$ is analyzed, which is the most related to the typical situation of concrete in the region.

\section{EXPERIMENTAL PROCEDURE}

\subsection{Specimen design}

Using the ACI design method (ACI 211-91, 2002), twelve prismatic specimens (150x150x300 mm) were made using Portland Compound Cement (CPC30R) standardized by Mexican standard (NMX-C-414-ONNCCE, 2014), and limestone rock aggregate typical of southeast Mexico. Table 1 shows the basic characteristics of concrete: curing, storage condition, type of cement, and water/cement ratio, and Table 2 the dosage of concrete. Each specimen was reinforced with six, 42-grade, 3/8" diameter carbon steel bars (350 mm long), placed at depths of 15, 20 and $30 \mathrm{~mm}$. Before placement in the specimens, the study area was marked on each bar, leaving a $150 \mathrm{~mm}$ long clear area in its center. The remaining bar was painted with epoxy paint and its end covered with isolating tape (Figure 1).

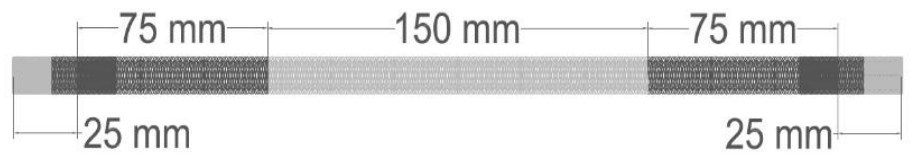

Figure 1. Marking of $150 \mathrm{~mm}$ unprotected area in the center of the bar (study zone).

The concrete was prepared using two water/cement (w/c) ratios: 0.45 (considered high-quality concrete in the study area), and 0.65 (considered low quality). Six specimens (old specimens 2007) were cured in a moist room for 28 days and then kept in storage for 233 days. The second set of six (new specimens - 2017), was cured for seven days by direct application of tap water, common practice in the study area, and kept in storage for 27 days.

Table 1. Basic characteristics of concrete, curing and storage type

\begin{tabular}{|c|c|c|c|c|}
\hline Specimen & Curing process & $\begin{array}{l}\text { Storage condition } \\
\text { (without control of } \\
\text { relative humidity and } \\
\text { temperature) }\end{array}$ & $\begin{array}{l}\text { Type of } \\
\text { cement }\end{array}$ & $\begin{array}{c}\text { Water/cement } \\
\text { ratio }\end{array}$ \\
\hline 2007 & $\begin{array}{l}\text { Moist room for } \\
28 \text { days }\end{array}$ & $\begin{array}{l}\text { Kept in semi- } \\
\text { controlled storage for } \\
233 \text { days after curing }\end{array}$ & \multirow{2}{*}{$\begin{array}{l}\text { Portland } \\
\text { Compound } \\
\text { Cement } \\
\text { (CPC30R) }\end{array}$} & $\begin{array}{l}0.45 \text { (3 specimens) } \\
0.65 \text { (3 specimens) }\end{array}$ \\
\hline 2017 & $\begin{array}{l}\text { Direct tap water, } \\
\text { few times/day } \\
\text { for } 7 \text { days }\end{array}$ & $\begin{array}{c}\text { Kept in semi- } \\
\text { controlled storage for } \\
27 \text { days after curing }\end{array}$ & & $\begin{array}{l}0.45 \text { (3 specimens) } \\
0.65 \text { (3 specimens) }\end{array}$ \\
\hline
\end{tabular}


Table 2. Mixture proportions for concrete

\begin{tabular}{|c|c|c|c|c|c|c|}
\hline \multirow{2}{*}{ Specimen } & \multirow{2}{*}{$\begin{array}{c}\text { w/c } \\
\text { ratio }\end{array}$} & \multicolumn{4}{|c|}{$\begin{array}{c}\text { Content of material } \\
\left(\mathrm{kg} / \mathrm{m}^{3}\right)\end{array}$} & \multirow{2}{*}{$\begin{array}{c}f^{\prime} c-28 \text { days } \\
\left(\mathrm{kg} / \mathrm{cm}^{2}\right)\end{array}$} \\
\hline & & cement & sand & gravel & water & \\
\hline \multirow{2}{*}{2007} & 0.45 & 408 & 681 & 800 & 287 & N/A \\
\hline & 0.65 & 277 & 739 & 868 & 280 & N/A \\
\hline \multirow{2}{*}{2017} & 0.45 & 456 & 638 & 757 & 205 & 231 \\
\hline & 0.65 & 315 & 740 & 757 & 205 & 159 \\
\hline
\end{tabular}

Before exposure, the inferior and superior sides of the specimens were painted with epoxy paint to limit the influence of aggressive agents to the lateral faces (Figure 2).

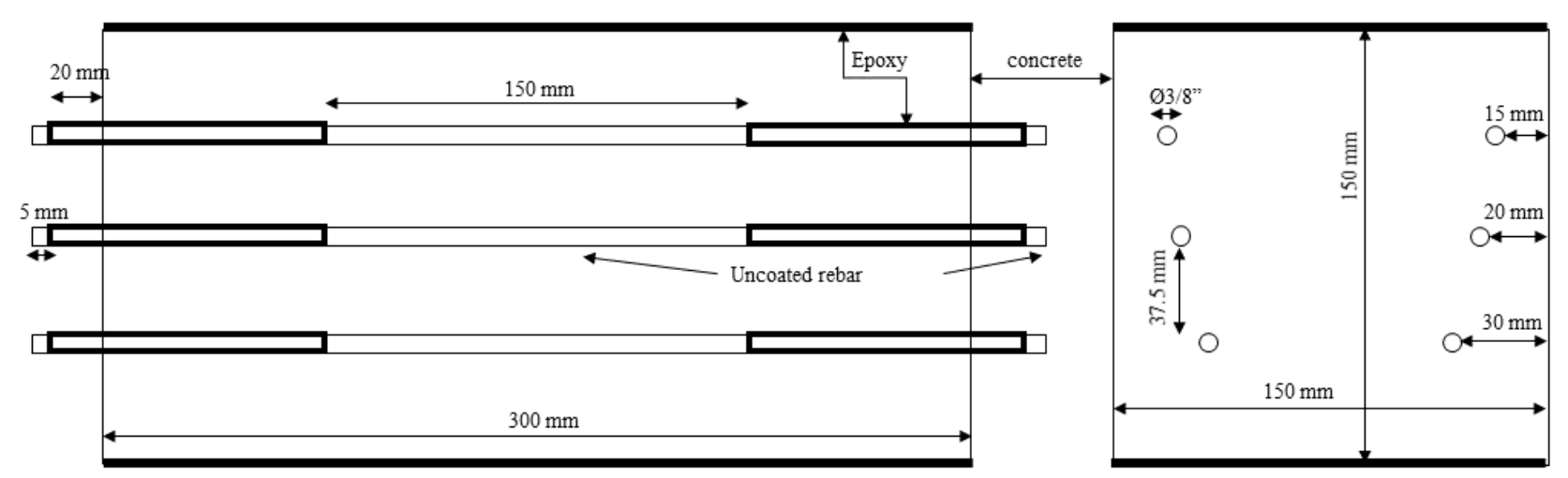

Figure 2. Specimen setup

\subsection{Exposure environment}

Specimens were exposed in a marine tropical environment on the north coast of the Yucatan Peninsula, Mexico. They were placed on the beach $50 \mathrm{~m}$ from the seashore and $0.95 \mathrm{~m}$ above the soil surface, positioning the area with most covering on the underside of the specimen Their orientation was such that they were exposed to different regional climate conditions: prevailing winds out of the northeast (PW) and non-prevailing winds out of the southwest (NPW) (Figure 3). The first set of specimens (2007) was exposed 261 days after cast and the second set (2017) 34 days after cast. 


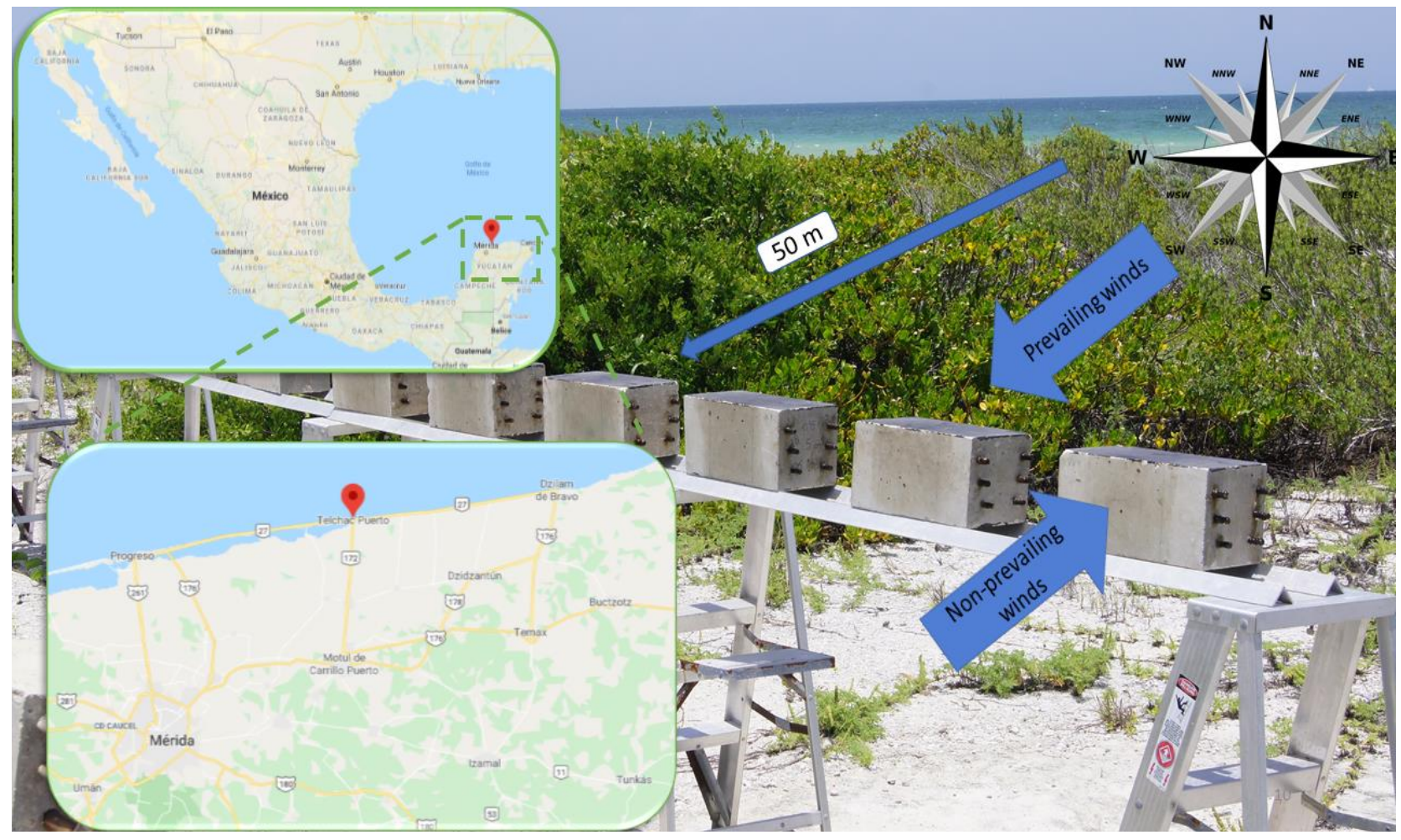

Figure 3. Setup of station for exposure of specimens.

\subsection{Corrosion measurements}

Steel reinforcement corrosion rate $\left(\mathrm{i}_{\text {corr, }} \mu \mathrm{A} / \mathrm{cm}^{2}\right)$, potential $\left(\mathrm{E}_{\text {corr }}, \mathrm{mV}\right.$ vs. $\left.\mathrm{Cu} / \mathrm{CuSO}_{4}\right)$, and concrete electrical resistance $\left(\mathrm{R}_{\mathrm{s}}, \mathrm{k} \Omega\right)$ were measured with a commercial portable corrosimeter with a confinement system, which uses the linear polarization resistance technique $\left(\mathrm{R}_{\mathrm{p}}\right)$ (Andrade \& Alonso, 1996). The value for electrical resistivity $(\rho, \mathrm{k} \Omega-\mathrm{cm})$ was calculated with equation (1), where $\mathrm{D}$ is the rebar diameter in $\mathrm{cm}$.

$$
\rho=2 R_{S} D
$$

For the 2007 specimens, electrochemical measurements were taken approximately every 90 days for 557 days, while for the second set, 2017, they were taken every 14 days for 279 days.

\section{RESULTS AND DISCUSSION}

\subsection{Passivation quality at initial ages}

For the present purposes, initial age is defined as the time during which the specimens exhibited electrochemical behavior in the passivation zone. Interpretation of passivation zone data was facilitated by using a conservative limit value of $0.1 \mu \mathrm{A} / \mathrm{cm}^{2}$ with a range of $0.1-0.5 \mu \mathrm{A} / \mathrm{cm}^{2}$ for depassivation. Figure 4 is a typical plot used for icorr recording versus time in small specimens exposed to a natural marine environment in different seasons. Even though three concrete covers $(15 \mathrm{~mm}, 20 \mathrm{~mm}$ and $30 \mathrm{~mm}$ ) were studied, this work discusses only data for the $20 \mathrm{~mm}$ concrete cover. This one is very common in the region's marine zone although applicable regulations demand thicker cover (NMX-C-530-ONNCCE, 2017). Other variables were the specimen's orientation (PW and NPW), included to identify any effect from wind, and concrete quality (w/c 0.45 and 0.65 ). 
In the high-quality concrete (w/c 0.45$)$ specimens, two data types were collected, one for exposure begun in 2007 (Table 1 and Figure 4a) and the other from 2017 (Table 1 and Figure 4b). The parameter of similar quality among specimens was mainly given by the type of cement and the w/c ratio. This was due to the lack of more information in 2007. However, one way to minimize the variability of the CPC was by comparing elements from the same family (2007 or 2017), where the difference between elements was more noticeable, from the same family, due to more important factors such as curing and storage. In fact, the data for exposure since 2007 (Figure 4a) were essentially stable during the first 557 days. The first 233 days corresponded to storage in a semicontrolled environment. From day 233 to day 557, they were exposed to a tropical marine environment, but the passivation condition continued almost unchanged.

On the other hand, the data for exposure 2017 (Figure 4b), corresponding to 27 days in laboratory conditions and 211 days of natural exposure, started to show differences between PW and NPW. These figures are confirming a difference between both passivation qualities which is mainly due to the suitable curing and storage process of specimens for 233 days at the non-aggressive environment, without any aggressive agents, for specimens from 2007 . Therefore, the quality of the passivation at initial ages allowed a subsequent better instantaneous electrochemical behavior for 2007 (Figure 4a) than for 2017 specimens (Figure 4b). The response of the low-quality concrete (w/c 0.65) was like that of the high-quality concrete (w/c 0.45) for both 2007 (Figure 4c) and 2017 (Figure 4d). However, instantaneous data for both w/c ratios seem to be a little bit dissimilar in 2017.

Although passivation zone behavior was stable, there were still doubts as to whether there were moments when, in response to changes in season (rainy and dry), the corrosion rate might have exceeded passivation zone values. As part of a larger project, specimens were built and exposed in 2017 for other purposes but clearly could serve to verify if this could influence the cumulative corrosion rate $\left(\mathrm{i}_{\text {cum }}\right.$ ), as reported recently (Castro-Borges et al., 2013, 2017; Melchers \& Li, 2006; Pedrosa \& Andrade, 2010; Rebolledo \& Andrade, 2010). Unlike those built-in 2007, these new ones were exposed to the marine environment almost immediately after curing. In a comparison of the two processing over the same time scale (Figures 4 a to $4 d$ ), the newer specimens exhibited behavior nearer the depassivation zone than the older specimens for all the studied variables. Curing, storage, and environmental variables affected, to a greater or lesser extent, the tendency towards depassivation. The parameters measured here helped to confirm passivation process quality at initial ages regardless of dependent variables (i.e. w/c and orientation). This will affect the planned specimen service life in terms of depassivation and propagation.

\subsection{Effects of electrochemical measurement periodicity on the data processing}

An obvious concern when taking frequent electrochemical measurements in passive steel reinforcement in concrete is possible damaging polarization which could affect the real $i_{\text {corr }}$ value. In modern times the damaging polarization is controlled, for example, by measuring the $i_{\text {corr }}$ through the linear polarization resistance with sweeping rates on the order of hundredths of millivolts and with cathodic polarization close to $20 \mathrm{mV}$ at the most. Therefore, and within these ranges, a higher measurement periodicity in the polarizations to measure corrosion is not detrimental to the studied rebar, and especially in field tests. This general subject has been addressed extensively, but no previous studies (Andrade \& Gonzalez, 1978; Andrade et al, 1986; Clément et al, 2012; Hansson et al, 2012) contain information about the possible effect of the periodicity of the measurements to interpret the meaning of the $i_{\text {cum }}$ under natural conditions. The most obvious difference between laboratory and field studies is that under laboratory conditions measurement intervals can be minutes, whereas under natural conditions intervals are normally on the order of days. The possible effect of polarization periodicity at initial ages in cumulative corrosion could occur in a natural environment in response to peaks in temperature and humidity, 
which would allow interpreting more accurately the changes in observed trends. Therefore, determining if electrochemical measurement periodicity influences the interpretation of passivation/depassivation in reinforced concrete with $i_{\text {cum }}$ under a natural environment during the initiation stage (passivation zone) is therefore quite technically and economically important. The $\mathrm{i}_{\text {corr }}$ confirm that measurement periodicity in the older or newer specimens did not affect data credibility since both specimen series exhibited the same tendencies (Figure 4). However, when

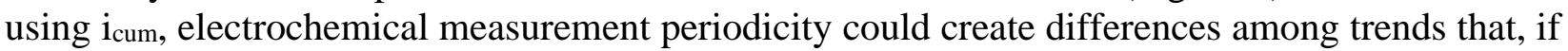
known, could be equivalent to tolerance levels used in destructive tests such as those used to compare electrochemical losses to gravimetric losses (Andrade \& Martinez, 2005). To approximate these differences the data in Figure 4 were analyzed, resulting in the data in Figure 5.

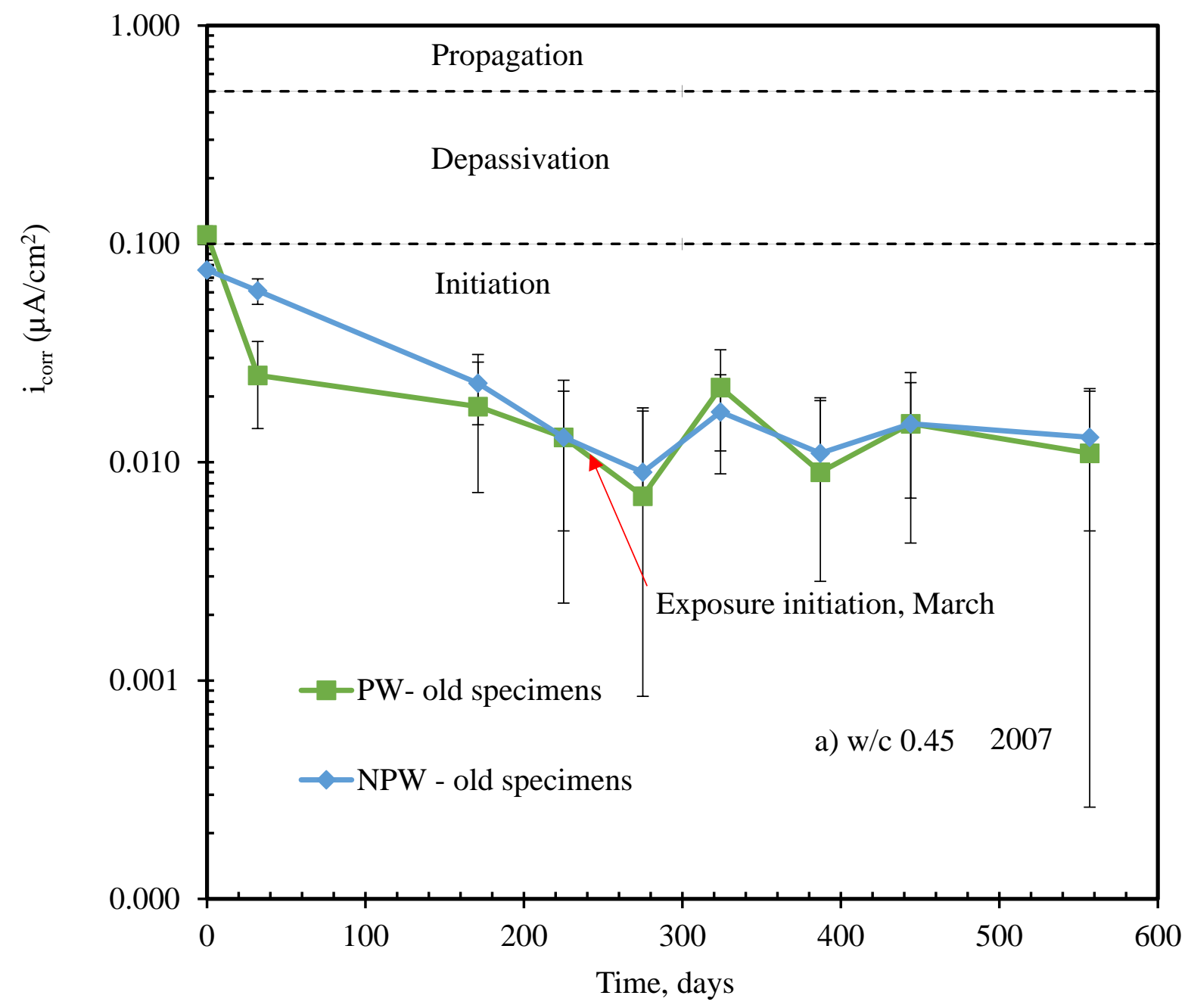



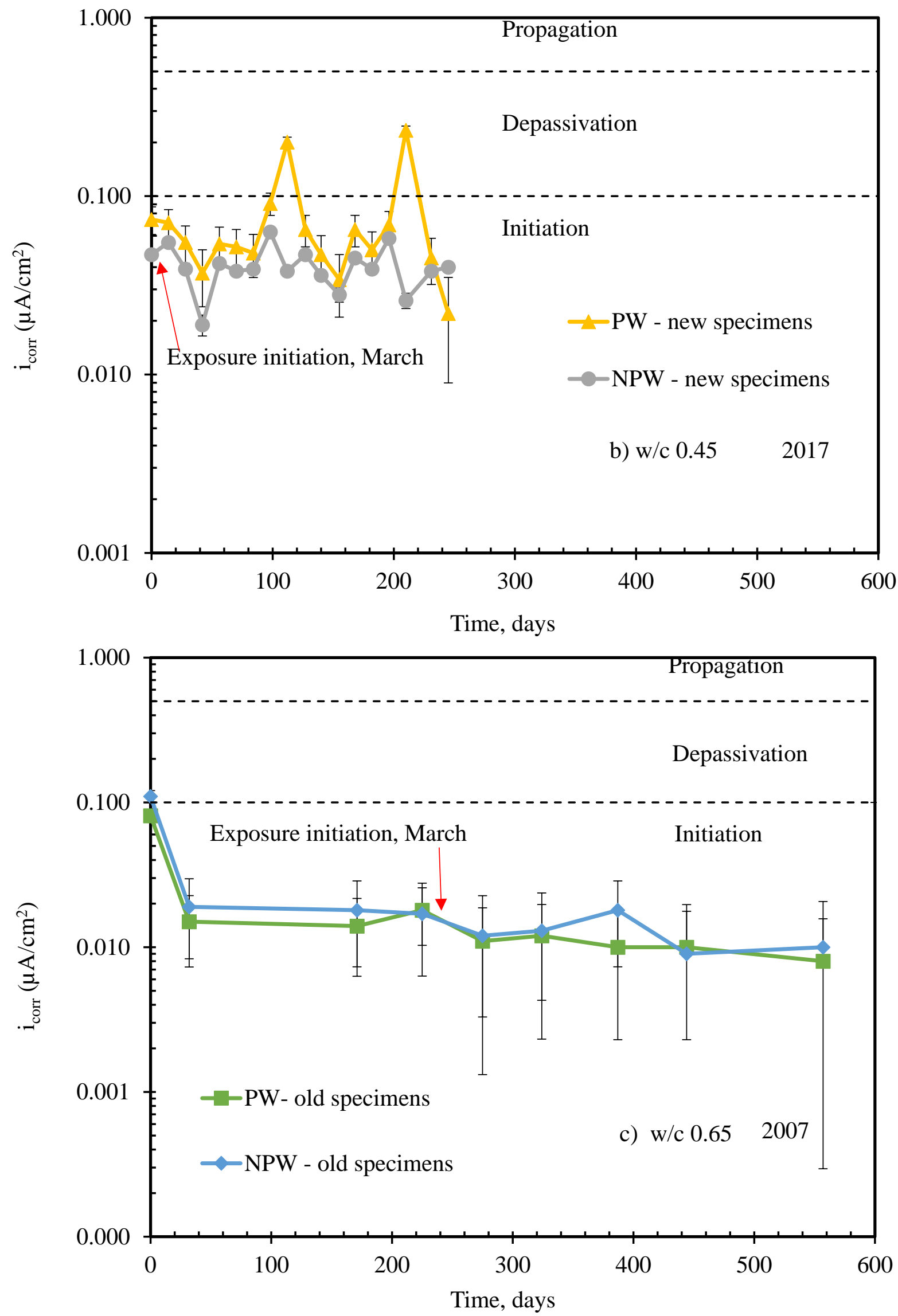

Passivation process quality in reinforced concrete: effects of polarization periodicity and passivation consolidation parameters on data processing 


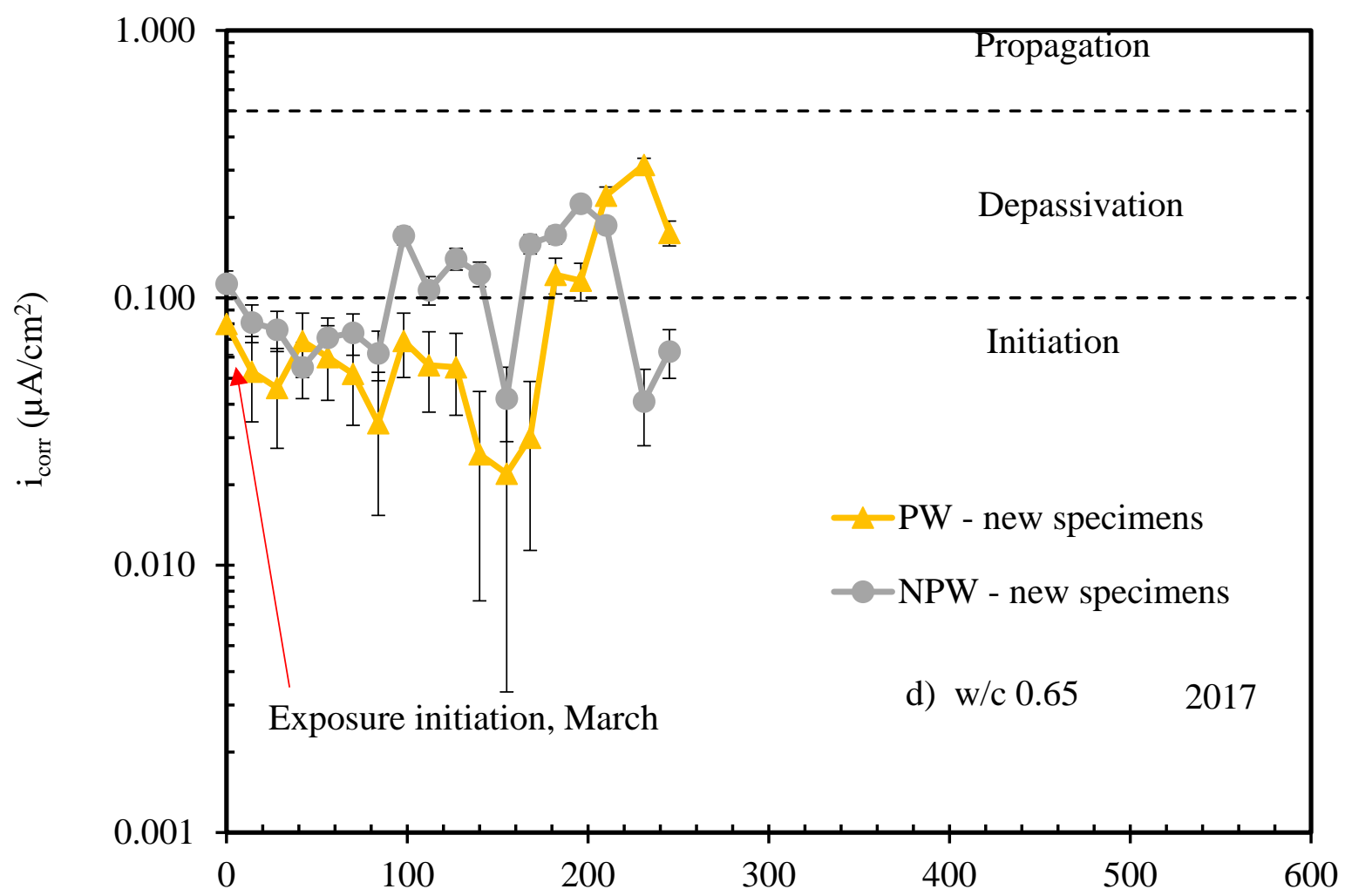

Time, days

Figure 4. Instantaneous corrosion rate vs. time: a) w/c 0.45, march 2007; b) w/c 0.45, march 2017; c) w/c 0.65, march 2007; d) w/c 0.65, march 2017.

Figure 5 shows a relation between sixteen measurements from March 2017 and four measurements from March 2007 that correspond, in both cases, to an exposure period of 211 days just after the beginning of the exposure to the environment. This relation 16/4 = 4/1 was taken as our reference to discuss the effect of the measurement periodicity on the interpretation of $i_{\text {cum. }}$. The term $i_{\text {cum }}$ can be defined as the sum of previous corrosion rates at each specific period (Castro-Borges et al., 2013) as given by equation (2):

$$
i_{\text {cum }}=\frac{\left(t_{f}-t_{i}\right) *\left(i_{\text {corrf } f}+i_{\text {corr } i}\right)}{2}+i_{\text {cumi }}
$$

Where:

$\mathrm{tf}_{\mathrm{f}}=$ Final day of the considered period

$\mathrm{t}_{\mathrm{i}}=$ Initial day of the considerer period

$\mathrm{i}_{\text {corr }}=$ Final $\mathrm{i}_{\text {corr }}$ of the considered period

$\mathrm{i}_{\text {corri }}=$ Initial $\mathrm{i}_{\text {corr }}$ of the considered period

$\mathrm{i}_{\text {cumi }}=$ Previously accumulated corrosion rate

When the Figure 5 data were analyzed using a 4/1 electrochemical measurement periodicity ratio, the difference between PW and NPW was up to $100 \%$ on the $i_{\text {cum value on specimens that did not }}$ have time to consolidate their passivation correctly (2017). Moreover, the tendencies between PW and NPW were inverted when considering the quality of concrete (w/c 0.45 or 0.65 ). This coincides and could be compared with tolerance due to errors that are attributed to data collection when electrochemical losses are compared to gravimetric losses (Andrade \& Martinez, 2005). However, 
this did not happen with those (2007) that were stored for 233 days and then exposed for 211 days, and that influenced the $\mathrm{i}_{\text {cum }}$ between PW and NPW of up to $40 \%$. In this case, it could mean the possibility of having a sharper tolerance if electrochemical losses were compared to gravimetric ones. The values of $100 \%$ and $40 \%$ probably mean a characteristic difference between specimens with not consolidated or consolidated passivation just before the beginning of the depassivation stage for the 4/1 ratio of measurement periodicity. The experimental and data collection limitations could slightly influence the results, so they do not necessarily apply under different conditions than those reported in this work. In equivalent form, if measurement ratios $>4 / 1$ were found and give even higher numerical differences in cumulative corrosion would place data credibility in question at initial ages (passivation zone). This is supported by the fact that the values of $i_{\text {corr }}$ (Figure 4) begin to show limit values close to $0.1 \mu \mathrm{A} / \mathrm{cm}^{2}$, the $100 \%$ of tolerance when comparing electrochemical vs gravimetric losses, and the inverted position of the PW and NPW tendencies in Figure 5.

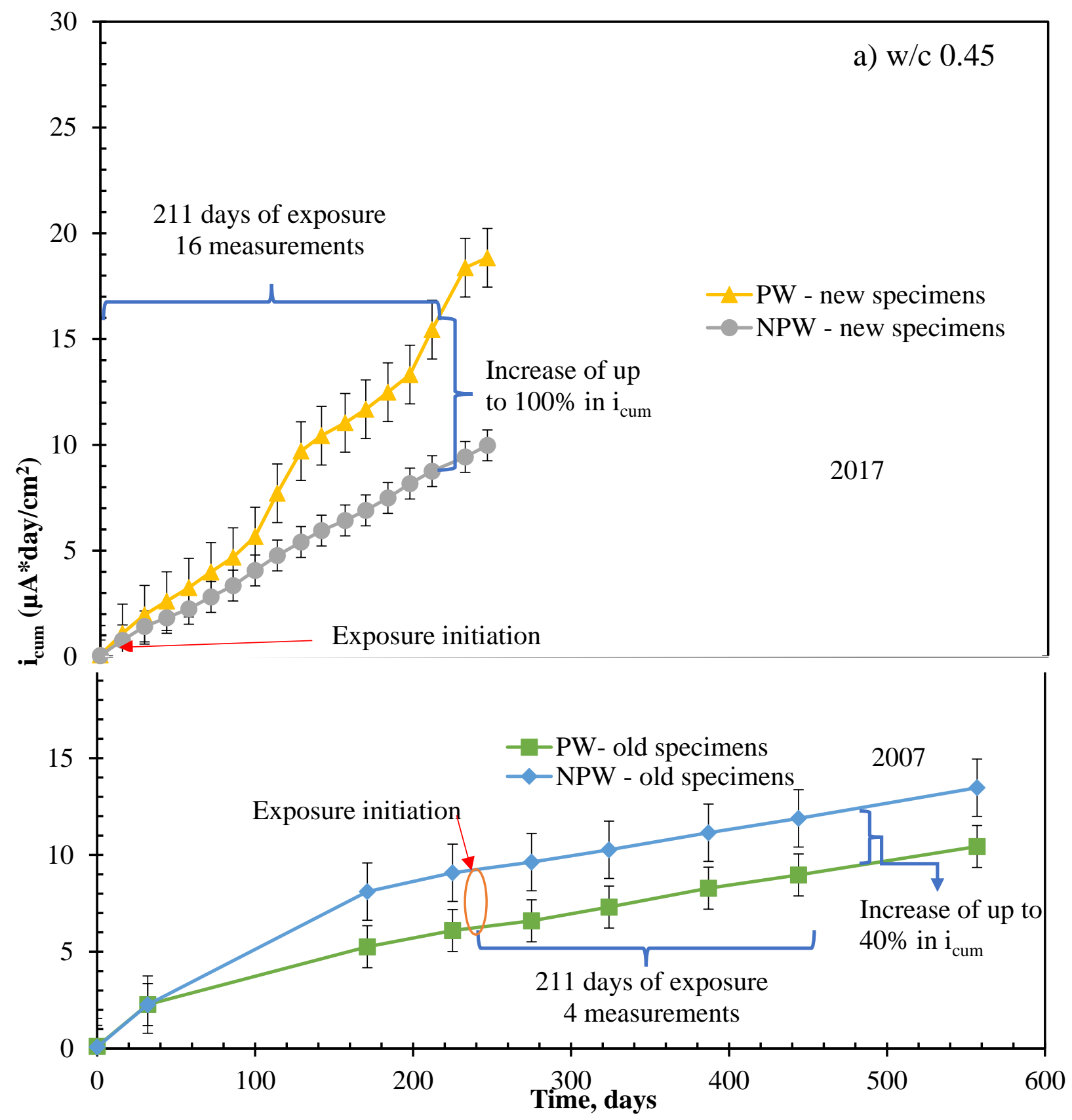




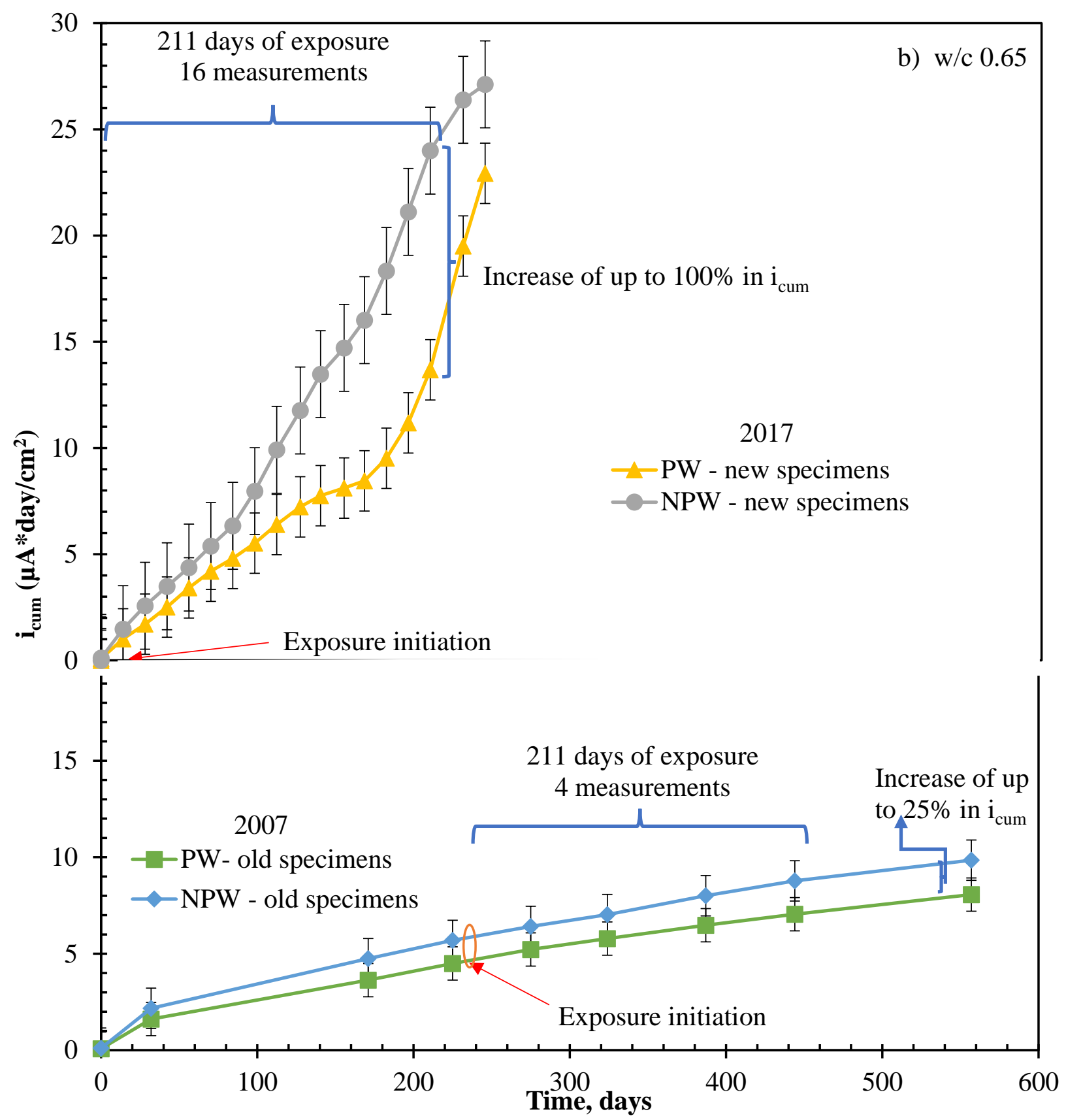

Figure 5. Cumulative corrosion rate vs. time: a) w/c 0.45 ; b) w/c 0.65 .

\subsection{Margin of uncertainty in cumulative corrosion}

In Figure 6, the icum of the specimens made in 2007 corresponds to the moment just before exposure to the tropical marine environment. These specimens were under semi-controlled conditions (storage in a laboratory, sheltered from the rain and the sun and without control of relative humidity and temperature) for the entire period. No significant variations were noted at a measurement periodicity of approximately three months (Figure 4). Considering that they were electrochemically stable in the passivation zone, cumulative corrosion immediately before exposure to the natural environment differed between surfaces (PW and NPW), from $1 \mu \mathrm{A} *$ day $/ \mathrm{cm}^{2}$ for w/c 0.65 to 5 $\mu \mathrm{A}^{*}$ day $/ \mathrm{cm}^{2}$ for w/c 0.45. Ahmad (2003) mentions that the lower the cement content, the lower the plastic consistency in the mix, which causes that the passivation of the steel does not occur uniformly, resulting in the depassivation; therefore, the results found could represent the margin of 
uncertainty when interpreting $\mathrm{i}_{\text {cum }}$ at initial ages (passivation zone) and these differences (1 $\mu \mathrm{A}^{*}$ day $/ \mathrm{cm}^{2}$ for w/c 0.65 to $5 \mu \mathrm{A} *$ day $/ \mathrm{cm}^{2}$ for w/c 0.45 ) can be deemed as characteristics of the materials used.

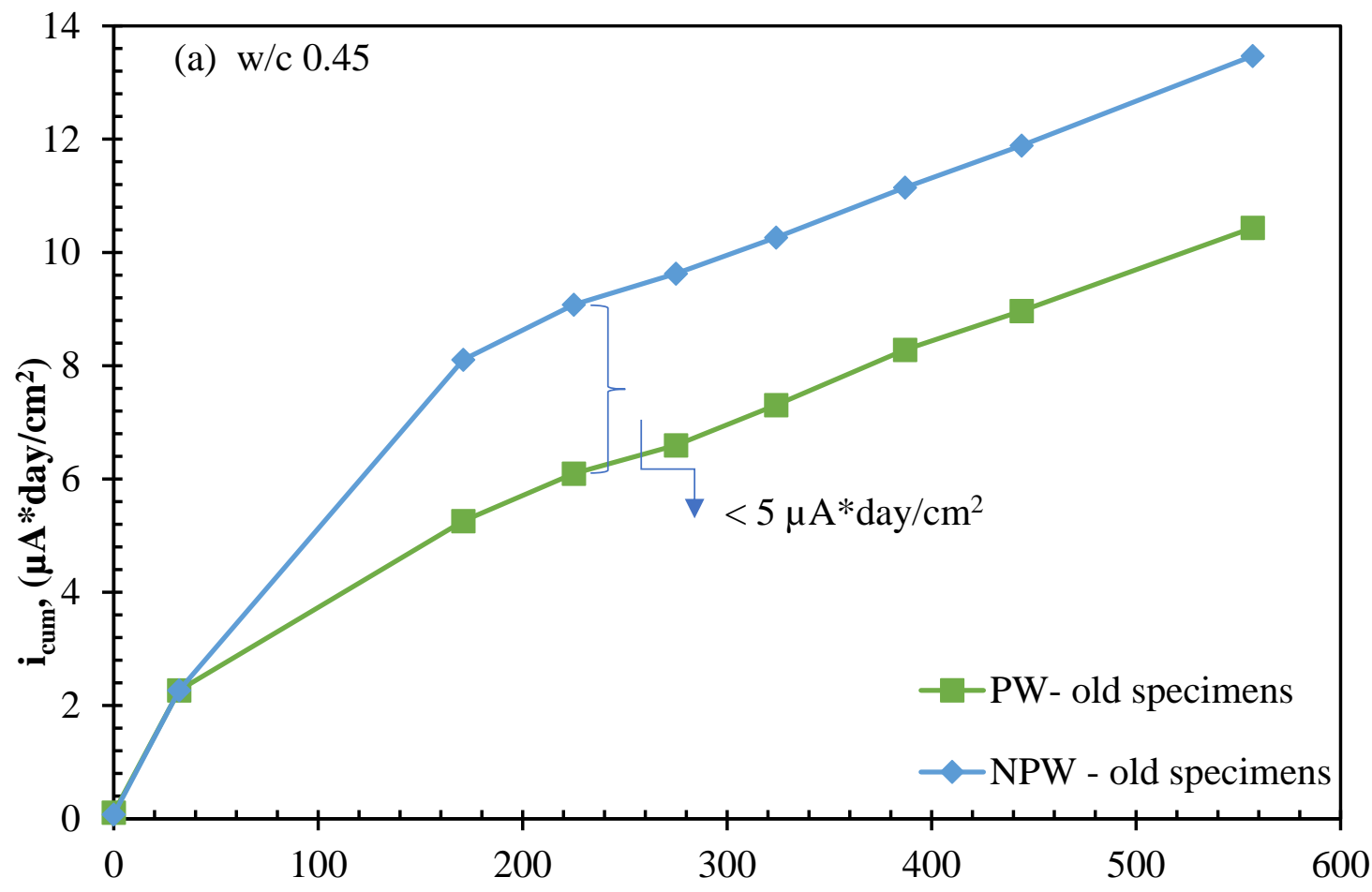

Time, days

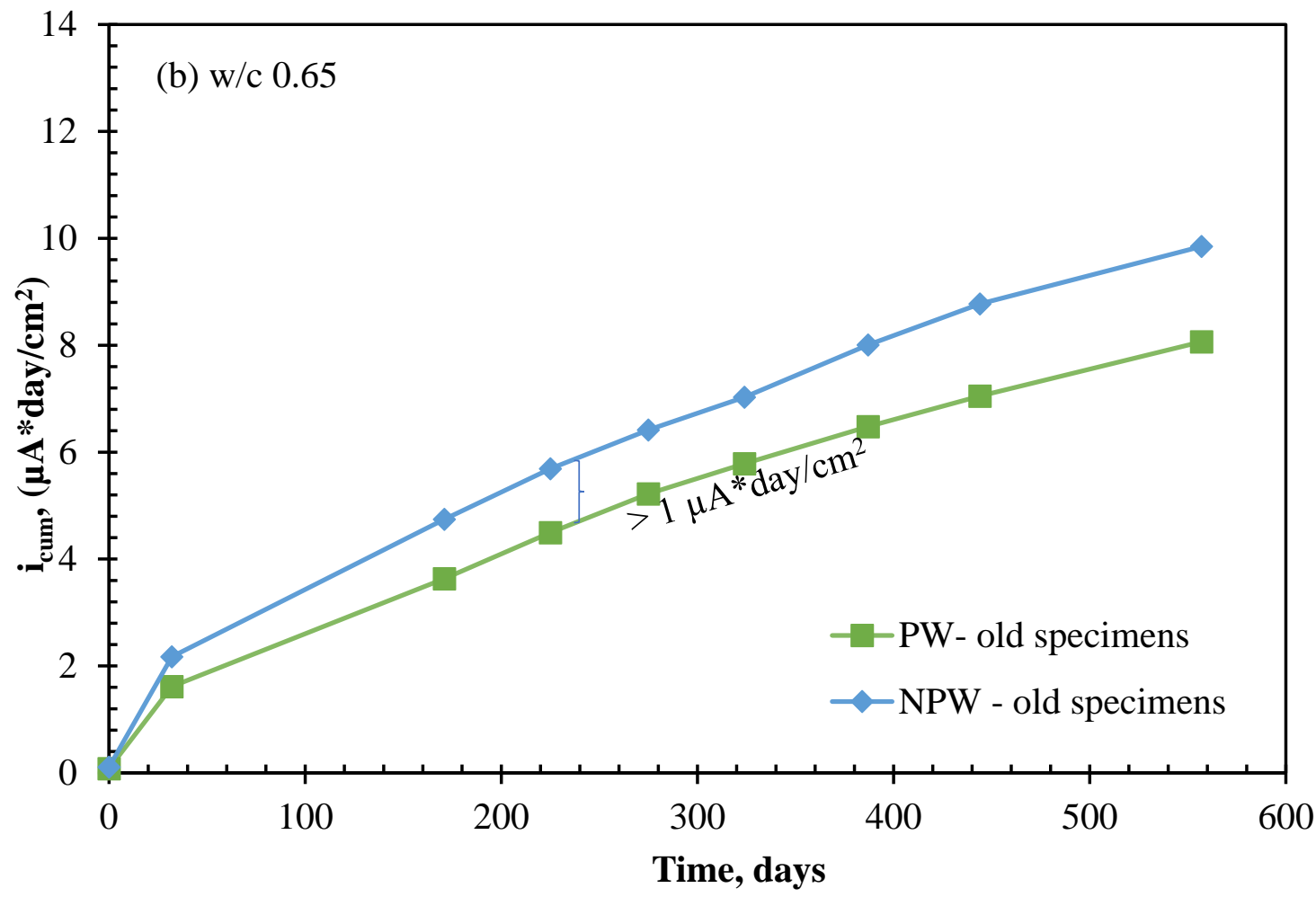

Figure 6. Uncertainty in cumulative corrosion rate vs. time: a) w/c 0.45; b) w/c 0.65. 


\section{CONCLUSIONS}

The reported results apply to these specific study conditions. Therefore, they can be extrapolated taking the appropriate precautions to other situations. In the present data, the parameters used in consolidating passivation quality at initial ages (i.e. curing, storage, and environmental variables) affect the tendency to depassivation regardless of the dependent variables (w/c ratio and orientation). This can affect the planned service life.

As and expected, the polarization produced by electrochemical measurement periodicity (days) in a tropical marine environment did not influence reinforced concrete passivation/depassivation during the initiation stage (passivation zone).

When electrochemical measurement periodicity was calculated at a $4 / 1$ ratio, it was found that it could numerically influence the cumulative corrosion value by up to $100 \%$. This is equivalent to the tolerance used in destructive tests comparing electrochemical losses to gravimetric losses.

Even though it is considered a largely qualitative method, $i_{\text {cum }}$ allows the detection of changes in the electrochemical behavior of reinforced concrete in the initiation stage (passivation). From a quantitative perspective, storage type after curing and before exposure to the environment, even in the initiation stage (before depassivation), had an influence that differed from $1 \mu \mathrm{A} *$ day $/ \mathrm{cm}^{2}$ for $0.65 \mathrm{w} / \mathrm{c}$ to $5 \mu \mathrm{A}^{*}$ day $/ \mathrm{cm}^{2}$ for $0.45 \mathrm{w} / \mathrm{c}$ in $\mathrm{i}_{\text {cum. }}$. This is equivalent to the margin of uncertainty when interpreting cumulative corrosion in the studied concrete qualities.

\section{ACKNOWLEDGMENTS}

The authors wish to acknowledge CINVESTAV-IPN Unidad Mérida and CONACyT for partial support. One of the authors, Jorge Briceño-Mena wish to acknowledge his scholarship from CONACyT for his Ph.D. studies.

\section{REFERENCES}

American Concrete Institute Committe (ACI) (2002). ACI 211-91. Standard Practice for Selecting Proportions for Normal, Heavyweight, and Mass Concrete. American Concrete Institute Committe 211, (Reapproved), 1-38.

Alonso, C., Andrade, C., Castellote, M., Castro, P. (2000). Chloride threshold values to depassivate reinforcing bars embedded in a standardized OPC mortar. Cement and Concrete Research, 30(7), 1047-1055. https://doi.org/10.1016/S0008-8846(00)00265-9

Andrade, C., Alonso, C. (1996). Corrosion rate monitoring in the laboratory and on-site. Construction and Building Materials, 10(5), 315-328. https://doi.org/10.1016/09500618(95)00044-5

Andrade, C., Gonzalez, J. A. (1978). Quantitative measurements of corrosion rate of reinforcing steels embedded in concrete using polarization resistance measurements. Materials and Corrosion, 29(8), 515-519. https://doi.org/10.1002/maco.19780290804

Andrade, C., Martinez, I. (2005). Calibration by gravimetric losses of electrochemical corrosion rate measurement using modulated confinement of the current. Materials and Structures, 38(283), 833-841. https://doi.org/10.1617/14297

Andrade, C., Merino, P., Nóvoa, X. R. R., Pérez, M. C. C., \& Soler, L. (1995). Passivation of Reinforcing Steel in Concrete. Materials Science Forum, 192-194, 891-898. https://doi.org/10.4028/www.scientific.net/MSF.192-194.891 
Andrade, C, Castelo, V., Alonso, C., González, J. A. (1986). The determination of the corrosion rate of steel embedded in concrete by the polarization resistance and AC impedance methods. Corrosion Science, 26, 961-970. https://doi.org/10.1016/0010-938X(86)90086-7

Ahmad, A., Kumar, A. (2013), Chloride ion migration/diffusion through concrete and test methods. International Journal on Advanced Scientific and Technical Research, 6(3), 151-180.

Ahmad, S. (2003), Reinforcement corrosion in concrete structures, its monitoring and service life prediction - A review. Cement and Concrete Composites, 25(4-5 SPEC), 459-471. https://doi.org/10.1016/S0958-9465(02)00086-0

Berke, N. S., Escalante, E., Nmai, C. K., \& Whiting, D. (1996). Techniques to Assess the Corrosion Activity of Steel Reinforced Concrete Structures - ASTM STP 1276. American Society for Testing and Materials.

Castro-Borges, P., Balancán-Zapata, M., López-González, A. (2013). Analysis of tools to evaluate chloride threshold for corrosion onset of reinforced concrete in tropical marine environment of Yucatán, México. Journal of Chemistry, 2013, 1-9. https://doi.org/10.1155/2013/208619

Castro-Borges, P., Balancán-Zapata, M., Zozaya-Ortiz, A. (2017). Electrochemical meaning of cumulative corrosion rate for reinforced concrete in a tropical natural marine environment. Advances in Materials Science and Engineering, Article ID 6973605. https://doi.org/10.1155/2017/6973605

Clément, A., Laurens, S., Arliguie, G., \& Deby, F. (2012). Numerical study of the linear polarisation resistance technique applied to reinforced concrete for corrosion assessment. European Journal of Environmental and Civil Engineering, (3-4), 1-17. https://doi.org/10.1080/19648189.2012.668012

Ghods, P., Isgor, O. B., McRae, G., Miller, T. (2009). The effect of concrete pore solution composition on the quality of passive oxide films on black steel reinforcement. Cement and Concrete Composites, 31(1), 2-11. https://doi.org/10.1016/j.cemconcomp.2008.10.003

Hansson, C. M., Poursaee, A., Jaffer, S. J. (2012). Corrosion of Reinforcing Bars in Concrete. The Masterbuilder, 15(3). https://doi.org/10.1179/000705980798275535

Huet, B., L'Hostis, V., Miserque, F., Idrissi, H. (2005). Electrochemical behavior of mild steel in concrete: Influence of $\mathrm{pH}$ and carbonate content of concrete pore solution. Electrochimica Acta, 51(1), 172-180. https://doi.org/10.1016/j.electacta.2005.04.014

Jiang, J. Y., Wang, D., Chu, H. Y., Ma, H., Liu, Y., Gao, Y., Shi, J., Sun, W. (2017). The passive film growth mechanism of new corrosion-resistant steel rebar in simulated concrete pore solution: Nanometer structure and electrochemical study. Materials, 10(4). https://doi.org/10.3390/ma10040412

Lopez, W., \& Gonzalez, J. A. (1993). Influence of the degree of pore saturation on the resistivity of concrete and the corrosion rate of steel reinforcement. Cement and Concrete Research, 23(2), 368-376. https://doi.org/10.1016/0008-8846(93)90102-F

Melchers, R. E., Li, C. Q. (2006). Phenomenological modeling of reinforcement corrosion in marine environments. ACI Materials Journal, 103(1), 25-32. Retrieved from http://0proquest.umi.com.library.newcastle.edu.au:80/pqdweb?did=1090660671\&Fmt=7\&clientId $=2974$ 4\&RQT $=309 \& \mathrm{VName}=\mathrm{PQD}$

ONNCCE (2014). NMX-C-414-ONNCCE. Industria de la Construcción - Cementos Hidráulicos Especificaciones y métodos de prueba. Organismo Nacional de Normalización y Certificación de la Construcción y Edificación, S. C.

ONNCCE (2015). NMX-C-501-ONNCCE. Industria de la construcción-Durabilidad de estructuras de concreto reforzado-Medición de velocidad de corrosión en campo-Especificaciones y método de ensayo. Organismo Nacional de Normalización y Certificación de la Construcción y Edificación, S. C.

ONNCCE (2017). NMX-C-530-ONNCCE. Industria de la construcción - Durabilidad - Norma 
general de durabilidad de estructuras de concreto reforzado - Criterios y Especificaciones. Organismo Nacional de Normalización y Certificación de la Construcción y Edificación, S. C.

Page, C. L. (2009). Initiation of chloride-induced corrosion of steel in concrete: Role of the interfacial zone. Materials and Corrosion, 60(8), 586-592. https://doi.org/10.1002/maco.200905278

Pech-Canul, M. A., Castro, P. (2002). Corrosion measurements of steel reinforcement in concrete exposed to a tropical marine atmosphere. Cement and Concrete Research, 32(3), 491-498. https://doi.org/10.1016/S0008-8846(01)00713-X

Pedrosa, F., Andrade, C. (2010). Study of corrosion rate variability in indoor and outdoor specimens. In Carmen Andrade \& J. Gulikers (Eds.), Advances in Modeling Concrete Service Life: Proceedings of 4th International RILEM (pp. 33-42). Madrid: Springer. https://doi.org/10.1007/978-94-007-2703-8

Poursaee, A., Hansson, C. M. (2007). Reinforcing steel passivation in mortar and pore solution. Cement and Concrete Research, 37(7), 1127-1133. https://doi.org/10.1016/j.cemconres.2007.04.005

Rebolledo, N., Andrade, C. (2010). From corrosion rate to accumulated corrosion depth or loss in cross section of reinforcements. In Carmen Andrade \& J. Gulikers (Eds.), Advances in Modeling Concrete Service Life: Proceedings of 4th International RILEM (Vol. 3, pp. 43-51). Madrid: Springer. https://doi.org/10.1007/978-94-007-2703-8

Troconis, O., Romero, A., Andrade, C., Helene, P., Díaz, I. (1998). Manual de inspección, evaluación y diagnóstico de corrosión en estructuras de hormigón armado (2nd ed.). Red Durar. and passivation consolidation parameters on data processing 